Итак, в целом выделяют четыре этапа профилактики преступного поведения несовершеннолетних. Все они имеют большое значение, но особое внимание, с нашей точки зрения следует уделять ранней профилактики, так как выявленные поведенческие отклонения на ранних стадиях имеют больше шансов на коррекцию.

Считаем, что еще в детском саду необходимо проводить психологическую диагностику девиаций, а так же воспитание в детях положительных нравственных качеств.

Следует так же отметить, что на сегодняшний день в России нет единой системы профилактики преступного поведения несовершеннолетних. В некоторых регионах проводится активная деятельность, в других регионах не реализуются даже обязательные программы. Поэтому в целом по России наблюдается низкая результативность профилактики преступности несовершеннолетних. Необходимо придать системе профилактики целостность, различные субъекты профилактики должны работать согласованно, а регионы должны обмениваться опытом, навыками и умениями, как между собой, так возможно и с другими странами. Для большей результативности необходимо привлекать к своей деятельности различные благотворительные организации и объединения.

\title{
ПСИХОЛОГИЧЕСКОЕ ПОРТРЕТИРОВАНИЕ ЛИЧНОСТИ: К ВОПРОСУ ОБ ЭФФЕКТИВНОСТИ ВИЗУАЛЬНОЙ ПСИХОДИАГНОСТИКИ
}

Стрельникова Э.В.

Под психологическим портретированием понимается создание целостной психологической характеристики личности. Область психологического портретирования очень широка, в той или иной мере она затрагивается практически всеми гуманитарными науками, в психологической же науке и практике эта тема является одной из главных и первоначальных.

Н.М.Ракитянский отмечает, что к созданию и использованию психологических портретов прибегают криминалисты, дипломаты, различные субъекты политического процесса, военные, правоохранительные ведомства, представители средств массовой информации. В повседневной социальной и производственной практике психологический портрет и его возможности активно используются бизнесменами, хозяйствующими субъектами для подбора, аттестации, подготовки кадров и работе с ними. [3] Деятельность психотерапевта или психологического консультанта также невозможна без предварительного психологического анализа клиента и составления его психологического портрета.

Однако психологическое портретирование несет в себе немалые методические трудности, поскольку до сих пор наблюдается отсутствие обобщающих систематизирующих концепций в этой сфере, влекущее за собой бессистемность методологического инструментария. Р.К.Хабибулин подчеркивает, что одним из важных моментов, порождающим известные 
сложности, является вопрос о соотношении номотетических и идеографических методик [4]. Так, интуитивно понятно, что портрет, являясь индивидуализированным описанием, создающим живой облик, располагает к использованию идеографических методик. Но с другой стороны, идеографический подход, который изначально не относится к естественнонаучным методам, вызывает у практикующих психологов различного рода сомнения. В итоге, как отмечает А.Г.Шмелев, на практике чаще всего применяются номотетические методики, и в результате такие «портреты» больше походят на сухой перечень обезличенных данных, практическое использование которых затруднительно и малоэффективно [5].

Использование такой процедуры составления психологического портрета личности, которое позволяло бы отследить как динамическую информацию о человеке (с использованием различного рода модификаций методов, направленных на изучение жизненного пути личности), так и статической оценки личностных особенностей (описание личности «здесь и сейчас» с помощью классических психодиагностических процедур) позволит, на наш взгляд, в значительной степени устранить методологические противоречия, о которых говорили Г.Олпорт, Д.А.Леонтьев, А.Г.Шмелев и другие отечественные и зарубежные исследователи.

Мы предполагаем, что психологическое портретирование как метод позволяет получить полное и всестороннее представление о человеке, а также спрогнозировать его поведение и степень эффективности взаимодействия с другими людьми и обладает значительным эвристическим потенциалом.

Составление психологического портрета личности помогает в диагностической и консультативной работе с клиентом для коррекции и оптимизации его развития. Для психолога в диагностической и консультативной работе важно уметь составлять психологический портрет личности клиента для наиболее эффективного использования его потенциала.

Одним из этапов составление психологического портрета личности традиционно является визуальная психодиагностика, осуществляемая параллельно с диагностическим или консультативным процессом. Однако, до сих пор в психологии нет единого мнения относительно эффективности и прогностичности данной процедуры.

В нашем экспериментальном исследовании мы поставили перед собой цель оценить возможную эффективность диагностики личностных особенностей на основании наблюдения за поведением человека (визуальной психодиагностики).

Исследование состояло из трех этапов: на первом этапе исследования проводилась видеозапись невербальных текс текстов общения и осуществлялась диагностика 12 различных личностных особенностей испытуемых с помощью традиционных психодиагностических методик. Были составлены психодиагностические заключения, описывающие такие личностные особенности, как: интроверсия/экстраверсия; адаптивность/дезадаптивность; приятие себя/неприятие себя; приятие других/неприятие других; эмоциональный комфорт/дискомфорт; 
внутренний/внешний контроль; доминирование/ведомость; лживость; эскапизм; интеллект; самооценка; агрессивность.

На втором этапе исследования оценка личности испытуемых осуществлялась «экспертами» на основе наблюдения за невербальными текстами общения испытуемых, записанных на видео. В качестве «экспертов» выступили студенты и магистранты-психологи, специальную подготовку в области визуальной психодиагностики и интерпретации невербальных текстов общения «эксперты» не проходили. Всего на данном этапе в исследовании приняло участие 57 человек. «Эксперты» на специальных бланках выносили «диагноз» относительно личностных особенностей испытуемых и отмечали те невербальные особенности поведения и внешности, которые послужили основанием для диагноза.

На третьем этапе исследования, полученные в ходе традиционного психодиагностического исследования и в ходе визуальной психодиагностики данные сопоставлялись. Данные традиционного психодиагностического исследования в данном случае рассматривались как эталонные. Подсчитывался коэффициент ранговой корреляции Спирмена между данными первого и второго этапа исследования.

Лучше всего по данным нашего исследования, испытуемые определяли такие личностные особенности, как: эскапизм, адаптивность/дезадаптивность, лживость и агрессивность (коэффициенты корреляции между данными визуальной и традиционной диагностики значимы на уровне $\mathrm{p} \leq 0,01)$.

Сложнее всего нашим «экспертам» оказалось определить уровень интеллекта на основании наблюдения невербальных текстов общения. Статистически значимых данных по этому показателю выявлено не было, но при этом следует отметить, что был получен отрицательный коэффициент корреляции (r= - 0,21), то есть «эксперты» оценивали невербальные тексты общения высокоинтеллектуального человека как свидетельствующие об относительно невысоком интеллекте. И, несмотря на то, что данная связь не является статистически значимой, полученные результаты нам кажутся интересными и нуждающимися в дополнительном изучении.

Чаще всего в качестве данных, на основании которых делался тот или иной вывод относительно личностных особенностей испытуемых, «эксперты» называли: специфику контакта глаз, лицевую экспрессию и сдержанность/избыточность жестикуляции.

Таким образом, визуальная психодиагностика как метод исследования способствует познанию и предварительной оценке личности и в таком качестве при составлении психологического портрета личности может быть достаточно эффективной.

\section{Литература}

1. Еремина Т.А.Визуальная психодиагностика- Ростов-на-Дону, изд-во «Феникс», $2010-208 \mathrm{c}$.

2. Лабунская В.А. Визуальная психодиагностика личности - Ростовна-Дону, 2011 - 122c. 
3. Ракитянский Н. М. Портретология власти. М.: Наука, 2004. -263 с.

4. Хабибулин Р.К. Дистантное психологическое портретирование субъектов политической власти//Вестник СПбГУ, 2011. Серия 12. Выпуск 3 C.57-65

5. Шмелев А. Г. Психодиагностика личностных черт - СПб.: изд-во «Речь», 2002- 480c.

\section{ПРОФЕССИОНАЛЬНО ВАЖНЫЕ КАЧЕСТВА В АДВОКАТСКОЙ ДЕЯТЕЛЬНОСТИ}

Теплякова А.П.

Научный руководитель: к.псх.н., доцент Макаревская Ю.Э.

Адвокату, как и любому другому профессионалу, требуется иметь набор определённых профессионально важных качеств, для того, чтобы успешно осуществлять свою адвокатскую деятельность[7].

Мы, на основе профессиограмм различных юридических специальностей (судья; адвокат; прокурор; следователь), используя метод сравнительного анализа, исследовали профессионально важные качества адвоката с целью выявления его универсальных и специфических профессионально важных качеств, применяемых им при осуществлении адвокатской деятельности.

Исследуя профессиограмму судьи, мы пришли к выводу, что к основным профессионально важным качествам при осуществлении правосудия относятся: честность, принципиальность, искренность по отношению к себе и другим; добросовестность, которая неразрывно связана с чувством долга; беспристрастность, которая позволяет принимать справедливые судебные решения и равно относится к лицам, участвующим в деле. Так же судья должен обладать объективностью и наблюдательностью, а так же способностью к передаче и приему вербальной информации. Так же стоит отметить, что для судей свойственна эмоциональная сдержанность[1].

Проанализировав профессиограмму следователя, мы выявили, что к профессионально важным качествам деятельности следователя при осуществлении предварительного следствия относят: логическое и аналитическое мышление; хорошую память; развитый образ мышления; коммуникативные и организаторские способности; хорошее владение письменной речью; внимательность; аккуратность; терпеливость; усидчивость; ответственность; настойчивость; целеустремленность; эмоциональная устойчивость.

Исследовав профессиограмму прокурора, мы пришли к выводу, что к ПВК успешного прокурора относят: способности к абстрагированию, обладанием широкого кругозора. Прокурор должен обладать гражданским мужеством и чувствам долга, а так же способностью устанавливать и поддерживать психологический контакт с различными участниками общения, преодолевать психологические и коммуникативные барьеры другой стороны. 